\title{
Water stress in indeterminate soybeans : no criti- cal stage in fruit development
}

\author{
Alix PIGEAIRE $\left({ }^{1}\right)$, Michel SEBILLOTTE $\left({ }^{*}\right)$ \& Robert BLANCHET \\ I.N.R.A., Station d'Agronomie, Centre de Recherches de Toulouse, B.P. I2, F 31.320 Castanet-Tolosam \\ (*) INA-PG, Chaire d'Agronomic, 16, nue Claude-Bernard, F 75231 Paris Cedex 05.
}

\begin{abstract}
The length of the period of maximal sensitivity to water stress in indeterminate soybeans is prolonged compared to other species. In order to determine whether this is due to length of flowering period. or to absence of a critical stage in fruit development, two cultivars (Hodgson and Kingsoy) were subjected to short, severe water stresses at threc different times during this period of maximum sensitivity. For both cultivars each water stress resulted in a significant reduction of seed weight per plant, essentially caused by a reduction in pod number. The profiles of pod number and seed number per node on the main stem were similar for each of the three water stresses for each varicty, despite these stresses being imposed at different times. Abortions were therefore not related to fruit age. but rather to the position of the organs on the plant. Secondary inflorescences were more affected than principal ones. For the principal inflorescences, the low and the high parts of the stem were more affected than the central one, and distal pods on the raceme more affected than the proximal ones. Theses positions are, generally, the most affected ones over a wide range of conditions.
\end{abstract}

Additional key words : Yield components, pod number, seed number. des organes reproducteurs.

Dans le but de déterminer si l'étalement de la période de sensibilité maximale à la sécheresse chez le soja de typo indéterminé est dû à l'étalement de la floraison ou à l'absence d'un stade criticjue dans le développement des organes reproducteurs, des contraintes hydriques fortes et de courte durée (arrêt total de la fourniture en eau pendant 2 a 3 jours) ont été appliquées aux deux variétés Hodgson et Kingsoy à 3 dates différentes au cours de la période de sensibilité maximale. Pour les 2 variétés, chacune des 3 contraintes hydriques a entraîné une réduction significative de la production de graines par plante provenant principalement d'une réduction du nombre de gousses par plante. Pour une même variété. les profils de nombres de gousses et de graines résultant des différentes contraintes appliquées étaient très voisins. L'avortement des organes reproductcurs ne s'est dono pas effectué en fonction de leur âge au moment de la contrainte. La position des organes sur la plante a par contro joué un rôle. L'avortement est plus fort sur les inflorescences latérales que sur les inflorescences centrales. Pour les inflorescences centrales, le bas et le haut de la tige sont plus touchés que la partie médiane, les gousses distales sur le racème plus touchées que les proximales. Ces positions sont celles qui, d’une façon générale, dans des conditions variées ont déjà les plus grandes probabilités d'avortement.

Mots clés additionnels : Composantes du rendement, nombre de gousses, nombre de graines.

\section{INTRODUCTION}

The effects of water stress on yield depend not only on the characteristics of this stress (intensity, duration) but also on the time of occurrence with respect to the

(1) Present adress : I.N.R.A., Station d'Agronomie, 17 rue Sully, F 21034 Dijon Cedex. development cycle of the plant. Sensitivity to water stress during plant development varies amongst species. Whereas maize has a critical period for yield at the time of female flower differentiation (ROBELIN, 1963), the maximum sensitivity of indeterminate soybean is less pronounced (only $30 \%$ reduction in yield compared to $55 \%$ for maize under identical water stresses) but the period of sensitivity is prolonged (SHAW \& LAING, 1966; MingeAU, 1974). 
The prolongation of the period of maximum sensitivity to water stress for indeterminate soybean may be due to the duration of flowering, or to the absence of a development stage of the pods and seeds particularly sensitive to water stress, or possibly to both these phenomena. Knowing which development stages of the reproductive organs are sensitive to each environmental factor is especially useful when one tries to explain the causes of low yields in a given place. If one knows the flowering dates for the successive nodes of the main stem and the number of pods that they carry, it is possible to link together the abnormal abortions at certain nodes with particular environmental factors. To do this, it is necessary to verify that these factors were actually stressful at the time when the organs that findlly aborted were the most sensitive, given their position on the plant and therefore their age. An example of this approach has been given by PIGEAIRE (1986) who observed that yield reduction in soybean was correlated with a period of low temperature at a critical stage of development previously identified by SAITO $c t a l$. (1970).

The aim of the present work was to determine whether the reproductive organs of indeterminate soybeans have a critical development stage with respect to water stress. Two varieties, reputed to react differently to water stress in the field, were subjected to conditions of high water stress over a short period applied at 3 different dates during the socalled phase: of maximum sensitivity. The identification of the reproductive organs which aborted following each water stress period has been achieved by comparing the numbers and positions of pods and seeds produced at each node of the treated and control plants.

\section{MATERIALS AND METHODS}

The 2 varieties used were Hodgson (maturity group I), reputed to be more sensitive to drought than Kingsoy (maturity group II). They were cultivated in the glasshouse in pots containing $8 \mathrm{~kg}$ of soil and 4 plants per pot. The pots were placed in individual basins joined together by plastic pipework. Apart from the period of drought applied, watering was carried out using an automatic solenoid valve which maintained a constant level of water in the basins. The temperature was regulated between $15^{\circ}$ and $33^{\circ} \mathrm{C}$ to avoid abortion due to excessively high or low temperatures. Excess nitrogen was supplied in mineral form, $\mathrm{NH}_{4} \mathrm{NO}_{3}$.

The pots of each of the 2 varieties were divided into 4 groups. The first group was the control and to the 3 other groups, one of the three water stress periods, $\Gamma 1$, T2 or T3, was applied. These water stresses were applied between the beginning of flowering and the end of pod elongation, before reaching stage R5 as described by FEHR et al. (1971). The actual dates of application were slightly different for each variety as their earliness of flowering differs (fig. 1). The interval between the beginning of $\mathrm{T} 1$ and $\mathrm{T} 2$, then $\mathrm{T} 2$ and $\mathrm{T} 3$ was 2 weeks and 1 week respectively.

The treatments consisted of simply cutting off the water supply so that the plants existed on the water reserve held in the pot. Water consumption was measured at 0900,1300 and 1700 each day during the water

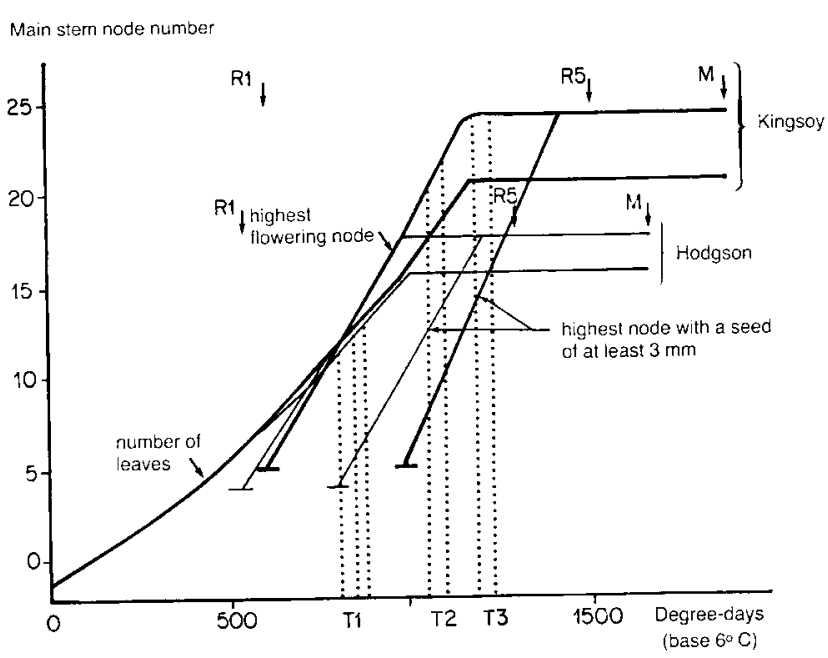

Figure 1

Position of water stress periods in relation to development of main stem for both caltivars Hodgson and Kingsol. The presentation follows PISE.tIRE (1984, 1986). Node 1 is for the first trifoliate. $R I=$ beginning of amthesis, $R \overline{5}=$ stage $R 5$ of $F E H R$ et al 's scale (1971), corresponding also with the end of the final stage in seed abortion (PIGEAIRE of al., 1986), $M=$ maturity.

Dates d'intervention des' contraintes hudriques par rapport au stade de développement de la tige principale pour les 2 variétés Hodgson et Kingsol. La représentation adoptée est c'lle de PIGEAIRE (1984, 1986) L' noud I 's' celui de la Ire fenille wifolice. RI - dibut floraison. R5 = stade R5 de l'échelle de FEHR et al. (1971), ce stade correspond anssi à la fin de franchissement du stade limite d'avortement des graines (PIGtarare el al., 1986) : $M=$ maturité

stress periods (fig. 2). They were determined by weighing each pot, in the 3 water stress treatments, and by measuring the water replaced to raise the level back to normal in the control. To avoid direct evaporation from the pots they were covered with polystyrene balls glued together, while each basin had a plastic cover with a hole fitting snugly around each pot. The dynamics of water consumption differed greatly between treatments due to climatic variations (fig. 2). The more the climatic demand was elevated (treatment T2), the more quickly the difference in transpiration between the treated plants and the control plants was observed. When the transpiration rate of the treated plants fell to about $20 \%$ of the control plants, in the last period measured, the pots were watered to stop the treatment and the automatic watering reinstalled. The duration of the treatments thus varied between 2.5 (T2) and 3.5 days (T1 Kingsoy - the treatment T1 was applied to Kingsoy half a day later than Hodgson which explains its lateness with respect to the latter). Important wilting occurred on all treatments. Some partial leaf necrosis was observed in T2 and T3. During treatment T3 the water consumption of the plants of the variety Hodgson, treated in T1 and T2, was also measured. This had regained 91 and $70 \%$ of the control level respectively.

The development stage of the control plants (fig. 1) was noted throughout their growth cycle as follows: number of leaves, number of the highest flowering node, and number of the highest node with a seed of at least $3 \mathrm{~mm}$ (Sinclair, 1984; PIGEAiRe, 1986). Node 1 is that with the first trifoliate leaf. Just before and after each treatment, the development stage of each individual stem, for all treated and control plants, was noted in the same manner. 

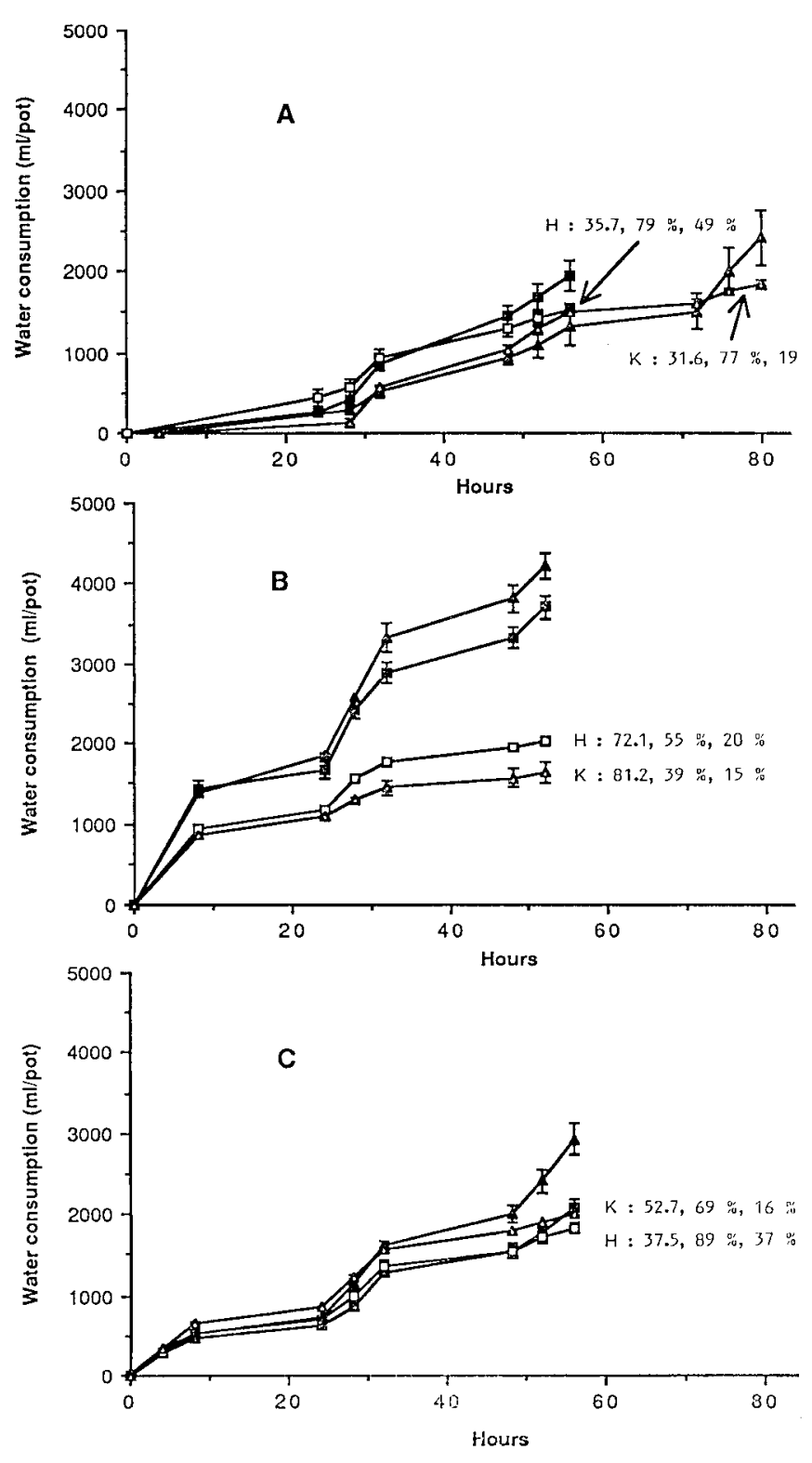

Figure 2

Cumulative water consumption during treatment $T 1(A), T 2(B)$, T3 (C). Measurements were made at 09, 13 and $17 \mathrm{~h}$. Vertical bars are standard errors of the means. The 3 numbers annotated for each variety on each figure represent respectively, the average water transpired by the control plants during the total treatment period in $\mathrm{ml} / \mathrm{pot} / \mathrm{hr}$, and the water transpired by the treated plants expressed as a percentage of the control, for the total treatment period and then for the last period of measurement. Hodgson ( $\mathbf{\square}$ ) control and (」) treated pots. Kingsoy $(\Delta)$ control and $(\Delta)$ treated pots.

Consommations d'eau cumulees pendant les contraintes $T I(A)$, T2 (B). T3 (C). Mesures effectuées à 9, 13 et $17 \mathrm{~h}$. Les barres verticales indiquent les écarts-type. Les 3 chiffres reportés pour chaque variété sur chaque figure représentent respectivement la consommation d'eau moyenne des plantes témoin pendant la période de contrainte en $\mathrm{ml} / \mathrm{pot} / \mathrm{h}$, et la consommation d'eau des plantes traitées exprimées en \% du témoin, pour la totalité de la période de contrainte, puis pour la dernière période de mesure. Hodgson, pots témoin ( $\mathbf{\square}$ ) et traités ( $\square$ ), Kingsov, pots témoin $(\mathbf{\Delta})$ et traités $(\Delta)$.

For the variety Kingsoy, only one sampling was made at harvest. For the variety Hodgson several samplings were made before and after each treatment, with both the control and treated plants. Some supplementary samples from the controls were taken afterwards to describe the end of the growth curves for the different organs; and from treatment T1 to describe the after effect of the treatment on the gain in dry matter. Using
2 pots each time, each sample consisted of the six most homogenous plants considering the development stage of the main stem at the treatment period. The position of the pods present at each node (central inflorescence, lateral inflorescence, left or right, position on the raceme) was determined by counting the scars of abcissed organs aided by a stereo microscope. The dry matter determinations were made by separating the plant into leaves and shoots, pods, and seeds.

\section{RESULTS}

\section{A. Consequences of water stress on seed production and dry matter accumulation}

In spite of the date of application, all water stress treatments resulted in a highly significant reduction $(\mathrm{P}=0.01)$ in seed production and total dry matter per plant (table 1). For variety Hodgson the smaller reduction in seed dry matter was due exclusively to a decrease in the number of pods produced. For variety Kingsoy it was also due to a decrease in the number of seeds per pod, and for the T3 treatment, a decrease in average seed weight (table 1). The harvest index for this last treatment was also significantly lower than that of the control.

The comparison of daily gains in dry matter between treated and control plants for the variety Hodgson are presented in table 2. During the stress period, the treatments caused, for the vegetative parts of the plants, either a reduction in dry matter gain (T1), or even, a loss of dry matter (T2 and T3). This difference between treatments is probably due to the fact that the water stress T1 was applied at the moment when the vegetative parts were still growing vigorously, while the other water stresses, $\mathrm{T} 2$ and especially $\mathrm{T} 3$, were preceded by a slowing of vegetative growth. The loss of leaves, that took place following the water stress period, was not compensated by subsequent gains in dry matter. The fruit always showed positive gains in dry matter. Water stress $\mathrm{T} 1 \mathrm{had}$ repercussions on the accumulation of dry matter following on from the treatment period itself. The senescence of vegetative parts was earlier than the control. The dry matter gains of the fruit also remained smaller, a consequence of a lower number of growing pods following some abortions.

\section{B. Identity of aborted reproductive organs}

Under the experimental conditions, the main stem was responsible for the greatest proportion of the plant's production, from 83 to $90 \%$ in each case. This proportion did not differ significantly between treated and control plants (table 1). The water stresses applied therefore affected the main stem and the branches with the same intensity. As a small number of reproductive organs were present on the branches, the identification of aborted organs was carried out using the main stem.

\section{Age of reproductive organs at the time of application of water stress}

The development stages of treated plants, noted just before and after each stress period, are presented in 
TABLE 1

Treatment effects on the production of seeds and total dry matter per plant at the time of harvest. MS = main stcm. For each cultiva, means in the same column followed b! the sane lotter are not significantly different $(P=0.01$. Duncan's test).

Effets des tratements sur la production de graines a de matiene seche torale par plante à la récolte. MS = tige principale.

Pour chaque variété, les moyennes d'une mìme colonme suivies d'une nême lettre ne sont pas significativement diffërentes au seuil l \% (lest de Dunctan).

\begin{tabular}{|c|c|c|c|c|c|c|c|c|c|}
\hline \multirow[b]{2}{*}{ Cultivar } & \multirow[b]{2}{*}{ Treatment } & \multicolumn{2}{|c|}{ Seed dry weight } & \multirow{2}{*}{$\begin{array}{l}\text { Total } \\
\text { dry matter } \\
\text { (g) }\end{array}$} & \multirow{2}{*}{$\begin{array}{c}\text { Harvest } \\
\text { index }\end{array}$} & \multirow{2}{*}{$\begin{array}{c}\text { Pod } \\
\text { number }\end{array}$} & \multirow{2}{*}{$\begin{array}{l}\text { Seed } \\
\text { number } \\
\text { pod }\end{array}$} & \multirow{2}{*}{$\begin{array}{c}\text { Seed } \\
\text { number }\end{array}$} & \multirow{2}{*}{$\begin{array}{l}\text { Weight } \\
\text { /seed } \\
\text { (mg) }\end{array}$} \\
\hline & & $\begin{array}{l}\text { Tolal } \\
(g)\end{array}$ & $\begin{array}{c}\% \text { from } \\
\text { MS }\end{array}$ & & & & & & \\
\hline \multirow[t]{4}{*}{ Hodgson } & Control & $27.52 a$ & $83 a$ & $53.46 a$ & $0.51 \mathrm{a}$ & $73.9 \mathrm{a}$ & $2.08 a$ & $154 a$ & $180 \mathrm{a}$ \\
\hline & $\mathrm{T} 1$ & $20.04 b$ & $86 a$ & $41.51 \mathrm{~b}$ & 0.48 a & $54.5 \mathrm{~b}$ & $2.01 \mathrm{a}$ & $110 \mathrm{~b}$ & $182 \mathrm{a}$ \\
\hline & $\mathrm{T} 2$ & $15.46 \mathrm{~b}$ & $85 a$ & $31.55 b$ & $0.49 \mathrm{a}$ & $44.9 \mathrm{~b}$ & $2.01 \mathrm{a}$ & $90 \mathrm{~b}$ & $169 \mathrm{a}$ \\
\hline & $\mathrm{T} 3$ & $17.88 \mathrm{~b}$ & $83 a$ & $34.18 \mathrm{~b}$ & $0.52 \mathrm{a}$ & $49.7 \mathrm{~b}$ & $1.92 a$ & $95 b$ & $187 a$ \\
\hline \multirow[t]{4}{*}{ Kingsoy } & Control & $39.22 \mathrm{a}$ & $85 a$ & $76.16 a$ & $0.52 \mathrm{a}$ & $78.4 a$ & $2.30 \mathrm{a}$ & $180 \mathrm{a}$ & $218 a$ \\
\hline & T1 & $22.74 b$ & $83 a$ & $48.11 \mathrm{~b}$ & $0.47 \mathrm{ab}$ & $51.8 \mathrm{~b}$ & $1.93 \mathrm{~b}$ & $100 \mathrm{~b}$ & $228 \mathrm{a}$ \\
\hline & $\mathrm{T} 2$ & $20.63 b$ & $89 a$ & $43.77 b$ & $0.47 \mathrm{ab}$ & $49.3 \mathrm{~b}$ & $1.99 \mathrm{~b}$ & $98 b$ & $209 \mathrm{a}$ \\
\hline & $\mathrm{T} 3$ & $15.72 \mathrm{~b}$ & $90 \mathrm{a}$ & $40.29 b$ & $0.39 \mathrm{~b}$ & $44.3 b$ & $1.97 \mathrm{~b}$ & $88 \mathrm{~b}$ & $177 \mathrm{~b}$ \\
\hline
\end{tabular}

TABLE 2

Changes in dry weight (mg.d ') for the main stem during (T7, T2, T3) and after stress (T7) - cv. Hodgson.

Gains journaliers de matiere sèche (nng.j') de la tige principale pendant la contrainte (T1,T2,T3).

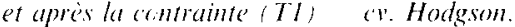

\begin{tabular}{|c|c|c|c|c|c|}
\hline & & & \multicolumn{3}{|c|}{$\begin{array}{l}\text { Dry matter gain (mg.d ') } \\
\text { for the main stem }\end{array}$} \\
\hline & & & Total & $\begin{array}{l}\text { Stems } \\
+ \text { leaves }\end{array}$ & Fruit \\
\hline \multirow[t]{3}{*}{ During the treatment } & $\mathrm{Tl}$ & $\begin{array}{l}\text { Control } \\
\text { Treated }\end{array}$ & $\begin{array}{l}721 \\
531\end{array}$ & $\begin{array}{l}512 \\
332\end{array}$ & $\begin{array}{l}209 \\
199\end{array}$ \\
\hline & $\mathrm{T} 2$ & $\begin{array}{l}\text { Control } \\
\text { Trcated }\end{array}$ & $\begin{array}{r}503 \\
-\quad 81\end{array}$ & $\begin{array}{r}172 \\
-231\end{array}$ & $\begin{array}{l}331 \\
150\end{array}$ \\
\hline & $\mathrm{T} 3$ & $\begin{array}{l}\text { Control } \\
\text { Treated }\end{array}$ & $\begin{array}{r}988 \\
-\quad 86\end{array}$ & $\begin{array}{r}302 \\
-505\end{array}$ & $\begin{array}{l}686 \\
419\end{array}$ \\
\hline After the treatment (') & $\mathrm{Tl}$ & $\begin{array}{l}\text { Control } \\
\text { Treated }\end{array}$ & $\begin{array}{l}746 \\
367\end{array}$ & $\begin{array}{r}237 \\
-\quad 31\end{array}$ & $\begin{array}{l}509 \\
398\end{array}$ \\
\hline
\end{tabular}

(1) From the end of the treatment to the date, in the controls, corresponding to the maximum dry matter accumulation in the vegetative plant parts, which was $7 \mathrm{I}$ days or 1294 degree-days (base $6{ }^{\circ} \mathrm{C}$ ) after emergence.

TABLE 3

Stages of development of the treated plans just hefore and after the treament.

Stades de developpement des plantes traitées juste avant et apress la contrainte.

\begin{tabular}{|c|c|c|c|c|c|c|c|}
\hline & & \multicolumn{2}{|c|}{ Number of leaves } & \multicolumn{4}{|c|}{ Highest } \\
\hline & & \multirow{2}{*}{ Before } & \multirow{2}{*}{ After } & \multicolumn{2}{|c|}{ Howering node } & \multicolumn{2}{|c|}{$\begin{array}{l}\text { Node with a seed } \\
\text { of at least } 3 \mathrm{~mm}\end{array}$} \\
\hline & & & & Before & After & Before & After \\
\hline \multirow[t]{3}{*}{ Hodgson } & $\mathrm{Tl}$ & $10.8 \pm 0.5$ & $12.1 \pm 0.6$ & $12.0 \pm 0.4$ & $14.2 \pm 0.6$ & $\left({ }^{2}\right)$ & \\
\hline & $\mathrm{T} 2$ & $16.0 \pm 1.0$ & $16.3 \pm 1.1$ & $18.0 \pm 1.3$ & $18.4 \pm 1.2$ & $11.3 \pm 1.0$ & $14.3 \pm 0.8$ \\
\hline & $\mathrm{T} 3$ & $(\bar{b})$ & & $(\overline{1})$ & & $17.1 \pm 0.9$ & $17.6 \pm 0.8$ \\
\hline \multirow[t]{3}{*}{ Kingsoy } & Tl & $11.2 \pm 0.5$ & $12.1 \pm 0.5$ & $11.2 \pm 0.8$ & $13.0 \pm 0.9$ & $(2)$ & \\
\hline & $\mathrm{T} 2$ & $16.6 \pm 0.6$ & $17.2 \pm 0.9$ & $19.0 \pm 1.1$ & $20.8 \pm 1.6$ & \multicolumn{2}{|c|}{ Not measured } \\
\hline & $\mathrm{T} 3$ & $20.8 \pm 0.4$ & $22.1 \pm 0.4$ & $24.5 \pm 0.8$ & $24.5 \pm 0.8$ & $12.5 \pm 0.8$ & $13.5 \pm 0.8$ \\
\hline
\end{tabular}

(') No further leaves expanding and flowering terminated.

(2) Stage not yet reached.

table 3. The standard deviations are small, resulting in coefficients of variation of between 5 to $7 \%$. In these conditions, the age of the reproductive organs at the time of water stress application can be considered as dependent only on the node number and the type of inflorescence which carry them. The lateral inflores- 
cences began, on average, to flower at the same time as the central inflorescences situated 3 nodes higher.

Figures 3 and 4 present respectively the numbers of pods and seeds per pod, on the central and lateral inflorescences of each node of the main stem. The profiles of pod numbers were more irregular than the profiles of seed numbers/pod.

For the same variety, the profiles resulting from the different water stress treatments had nearly the same forms (fig. 3 and 4), which means that the aborted reproductive organs were the same whatever the date of application of the water stresses. Moreover, between central and lateral inflorescences, there was not a 3-node difference in the position of the aborted organs (fig. 3 and 4). Thus abortion did not depend on the age of the reproductive organs at the moment water stress was applied.
A

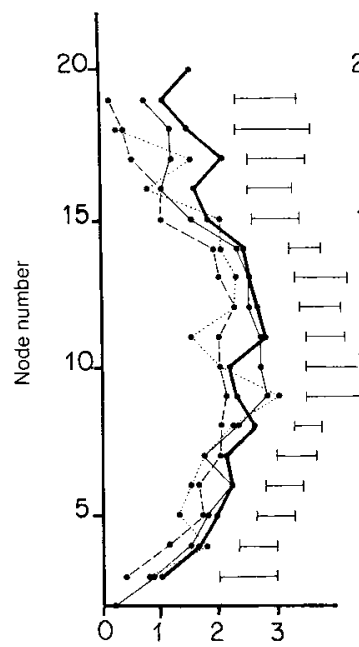

B

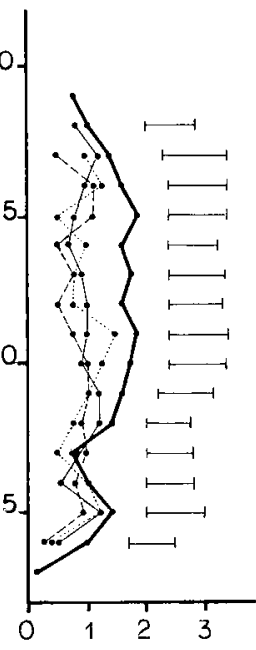

C

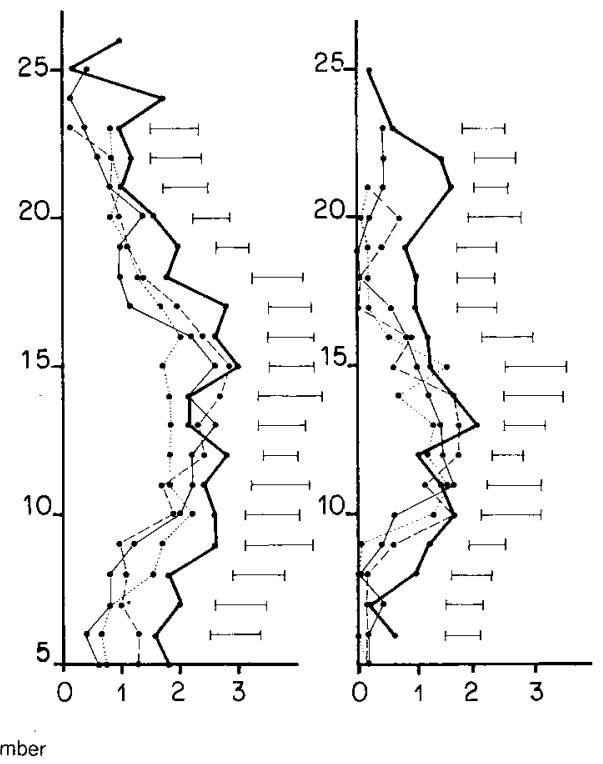

Figure 3

Pod number

Pod numbers per node on the main stem. A and $B, c v$. Hodgson, central $(A)$ and lateral $(B)$ inflorescences. $C$ and $D,(v$. Kingsoy, central $(C)$ and lateral (D) inflorescences. ( $(\longrightarrow)$ control, ( - $T 1,(\cdots) T 2,(--)$ T3. Horizontal bars indicate the lsd $(P=0.05)$.

Profils des nombres de gousses par noud sur les tiges principales. A et $B, c v$. Hodgson, inflorescences centrales $(A)$ et laterales $(B)$. $C$ et $D, c v$. Kingsov, inforescences centrales $(C)$ et latérales $(D) .(-)$ Témoin, ( $(-) T I,(--) T 2,(-) T 3$. Les barres horizontales indiquent les ppds $(P=0.05)$.

A

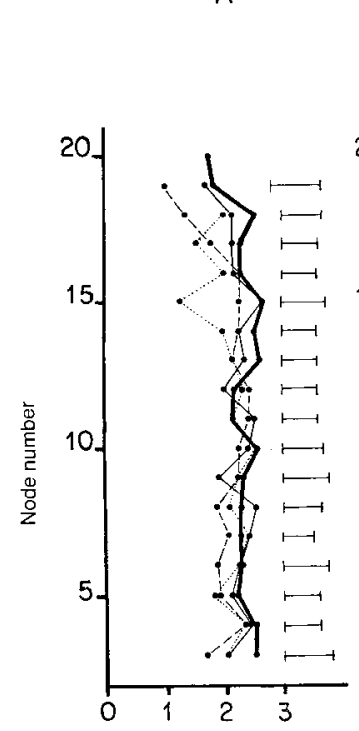

B

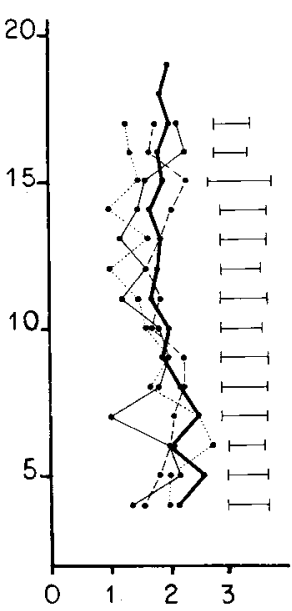

C

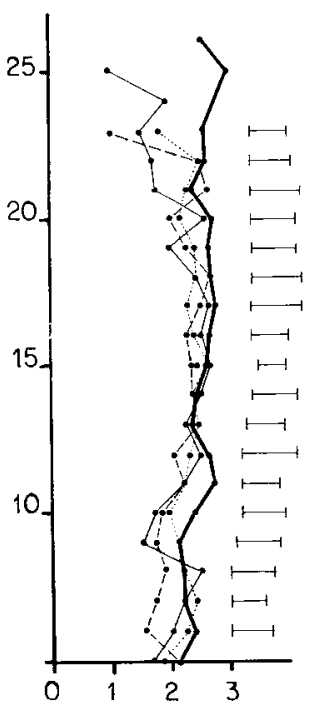

D

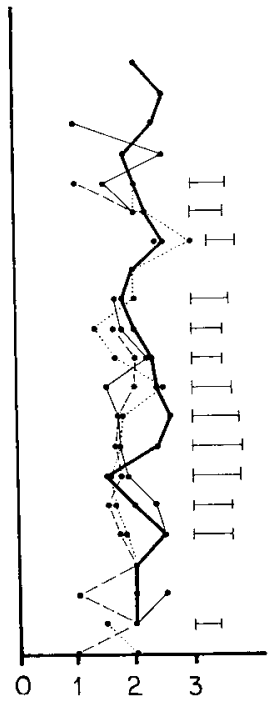


A

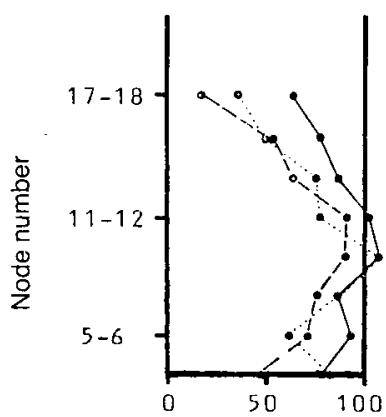

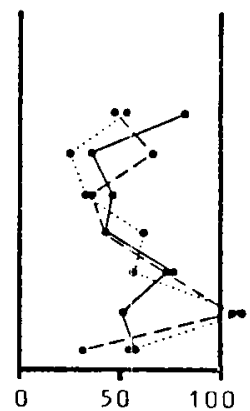

C

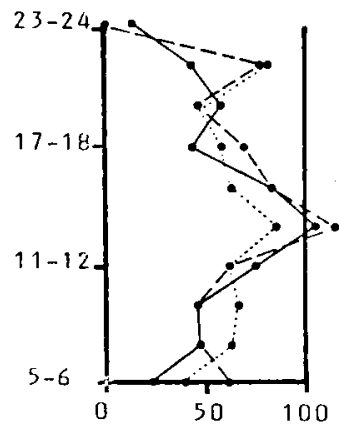

D

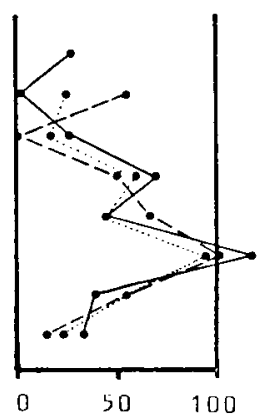

Seed number (\% control)

Figure 5

Seed mumbers per group of wo nodes as percentages of the commols. Codes of treaments and figures are the same as in figure 3.

Profils des nombres de graines par groupe de 2 nouds, en valcurs rilatives par rapport an témoin. Codes des traitements et des figures identiques à ceux de la figure 3 .

\section{Position of reproductive organs on the stem}

The position of aborted reproductive organs can be examined in a global fashion (i.e., abortion of pods and seeds per pod together) with the aid of figure 5 showing the numbers of seeds per node for the treated plants relative to the controls. For easy comprehension the nodes were grouped in twos. Generally, the lateral inflorescences (B and D, fig. 5) were more affected than the central inflorescences (A and $\mathrm{C}$, fig. 5). The central inflorescences for both varieties, and the lateral inflorescences for Kingsoy, tended to be more affected at the base and shoot tip rather than the middle part of the stem, whereas the lateral inflorescences for Hodgson showed more of an affect on the entire stem. High relative values for one group of nodes for each variety were due more to a lower than normal number of pods for the control plants, than to a particularly high number for the treated plants (fig. 3). Within the central inflorescences, the distal pods on the raceme were more affected. The relative numbers of seeds decreased systematically from pod position 1 on the raceme to pod position 3 or more (table 4 ).

\section{DISCUSSION}

The effects of water stress observed in this trial agree with the results generally obtained for indeterminate soybean. The three water stresses applied at different dates, but always during the period of maximum sensitivity to drought, all had important effects on plant production (SHAW \& LAING, 1966 ; MingeAU, 1974). The yield component most affected was number of pods per plant (Puech et al., 1974 ; BLANCHET et al., 1977).

The varietal effect was the inverse of that which is generally described in the field. Variety Kingsoy was more affected than variety Hodgson, which is reputed to be particularly sensitive to drought (VIDAL et al., 1981). During this trial, the intensity of water stress suffered by variety Kingsoy was always greater if one considers the drop in water consumption observed for the treated plants (fig. 2). Apart from the period $\mathrm{T} 1$ which commenced later for Kingsoy, the water consumption of control plants was generally greater for Kingsoy than Hodgson, reflecting probably the difference in leaf area index between the two varieties. Consequently, the transpiration of the treated plants was greater for the variety Kingsoy. One observes that for Kingsoy the

TABLE 4

Total sced numbers of the central inflorescences of the main stem according to the position of the pod on the raceme, as percentages of the controls). Values for the controls are given in parenthesis.

Nombre total de graines des inflorescences centrales de la tige principale selon le rang des gousses sar le racène. Valeurs relatives par rapporl an témoin. Entre parenthèses, valears absolues pour le témoin.

\begin{tabular}{|c|c|c|c|c|c|}
\hline & & \multicolumn{4}{|c|}{ Pod position on the raceme } \\
\hline & & 1 & 2 & 3 & $\Sigma(>3)$ \\
\hline Hodgson & $\begin{array}{c}\text { Control } \\
\text { T1 } \\
\text { T2 } \\
\text { T3 }\end{array}$ & $\begin{array}{c}100(33.1) \\
99 \\
81 \\
87\end{array}$ & $\begin{array}{c}100(28.9) \\
85 \\
64 \\
73\end{array}$ & $\begin{array}{c}100(16.1) \\
73 \\
36 \\
37\end{array}$ & $\begin{array}{c}100(3.6) \\
0 \\
7 \\
0\end{array}$ \\
\hline Kingsoy & $\begin{array}{c}\text { Control } \\
\text { T1 } \\
\text { T2 } \\
\text { T3 }\end{array}$ & $\begin{array}{c}100(46.2) \\
68 \\
66 \\
70\end{array}$ & $\begin{array}{c}100(37.2) \\
57 \\
63 \\
48\end{array}$ & $\begin{array}{c}100(19.8) \\
35 \\
50 \\
46\end{array}$ & $\begin{array}{c}100(3.0) \\
13 \\
47 \\
33\end{array}$ \\
\hline
\end{tabular}


reduction of total seed weight was due not only to a decrease in the number of pods but also in the number of seeds per pod, whereas for Hodgson it was due only to a reduction in the number of pods. This suggests that water stress provokes firstly abortion of flowers and pods and then abortion of seeds. These results are not contradictory with the varietal differences in drought resistance observed in the field (SPECHT et al., 1986), where the role of root colonization of the soil comes into play (PLANCHON, 1984), a factor which cannot express itself in a pot.

The harvest indices were constant when only the component number of pods was affected. They were statistically different from the control, only when the seed weight had been affected (Kingsoy T3). It seems that soybean can counterbalance to a certain point the negative effects of photosynthesis (table 2) by internal redistribution of nutritive elements in favour of the seeds. For example, if one considers daily seed growth rate after the end of the drought period for treatment $\mathrm{T} 1$ and the control, one observes respectively, 3.62 and $3.31 \mathrm{mg} \mathrm{day}^{-1}$ (from table 1 value, divided by treatment length, and post treatment periods), which are very similar; by comparison the leaves continuously lost dry matter with T1. There was also perhaps a partial degradation of the root system which inhibited the treated plants from regaining the transpiration rate of the control. During period T3, the transpiration rate of $\mathrm{T} 1$ was $90 \%$ that of the control and that of $\mathrm{T} 2$ was $70 \%$; which indicates an after effect of the treatments of at least one week. This after effect is also visible on the total growth rate of the main stem after water stress T1 (table 2). The loss of seed weight observed uniquely with T3 Kingsoy could therefore be due to an after-effect of treatment T3. This treatment was the last and it was more severe for Kingsoy than for Hodgson (fig. 2, tabl. 1).

Under water stress conditions, the probability of different organs aborting depends on their position on the plant. The organ positions most affected by water stress are in fact those already most affected by abortion on plants well supplied with water. Generally the lateral inflorescences are smaller, produce smaller seeds and less of them than the central inflorescences (SPAETH \& SINCLAIR, 1984 ; SPOLLEN et al., 1986). The probability of abortion is greater for pods in a higher position than a lower position on the raceme (HUFF \& DYBING, 1980 ; BRUN \& BETTS, 1984). Generally speaking the profiles of the numbers of pods, or seeds, per node show higher values for the middle part of the stem, regardless of whether the treatments were irrigated or not (CARLSON et al., 1982 ; HERBERT \& LITCHFIELD, 1982).

The explanation of the fact that abortions took place preferentially at the base and the extremity of the stem, under water stress, probably lies in the way in which water stress affects the plant; as it is in those parts of the stem that wilting is first observed to occur. The onset of abortion may happen from different causes, such as: a direct effect of drought resulting in a lethal change in water potential or water content within the organ concerned; indirect effects, such as a reduction in the production of assimilates, or a lowering of the transpiration rate which causes a reduction in xylem flow transporting the cytokinins necessary for the development of the young fruit (CARLSON et al., 1987). Whatever is the cause of abortion, in the absence of a stage of development particularly sensitive to water stress, it seems logical that the aborted organs correspond to the positions on the plant that are most quickly and severely affected by water stress. The reasons for differences in behaviour under water stress between different parts of the stem remain to be clarified.

Whatever the variety, a stage of development particularly sensitive to water stress for the reproductive organs has not been observed as was the case for the influence of low temperature (SAITO et al., 1970). When water stress is induced, organs of all ages abort, from the pre-floral stage until the final stage in seed abortion (PIGEAIRE et al., 1986). This diversity in the age of aborted organs has already been observed by PUECH et al. (1977) in various experimental conditions. This results in a long period of maximum sensitivity to drought, which lasts until all reproductive organs have passed the final stage in seed abortion.

\footnotetext{
Recule 6 octobre 1987 Accepté le 25 aoûl 1988
}

\section{REFERENCES BIBLIOGRAPHIQUES}

Blanchet R., Gelfi N., Bose M., 1977. Relations entre consommation d'eau et production chez divers types variétaux de soja. Ann. agron., 28, 261-275.

Brun W. A., Betts K. J., 1984. Source/sink relations of abscising and non abscising soybean flowers. Plant physiol, 75, 187-191.

Carlson R. E., Karimi-Abadchi M., Shaw R. H., 1982. Comparison of the nodal distribution of yield components of indeterminate soybeans under irrigated and rain-fed conditions. Agron. J., 74, 531-535.

Carlson D. R., Dyer D. J., Cotterman C. D., Durley R. C., 1987. The physiological basis for cytokinin-induced increases in pod set in IX93-100 soybeans. Plant physiol., 84, 233-239.

Fehr W. R., Caviness C. E., Burmood D. T., Pennington J. S., 1971. Stage of development descriptions for soybeans, Glycine max (L.) Merril. Crop Sci., 11, 929-931.

Herbert S. J., Litchfield G. V., 1982. Partitioning soybean seed yield components. Crop Sci., 22, 1074-1079.

Huff A., Dybing C. D., 1980. Factors affecting shedding of flowers in soybean. J. exp. Bot., 31, 751-762.

Mingeau M., 1974. Etude de la sensibilité du soja à la sécheresse. Informations techniques CETIOM, 47, 1-14.
Pigeaire A., 1984. Elaboration des composantes du rendement chez te soja de type indéterminé (cv. Hodgson et Kingsoy). Thèse de docteuringénieur. Institut National Polytechnique de Toulouse, $163 \mathrm{p}$.

Pigeaire A., 1986. Propositions pour lc diagnostic cultural chez le soja de type indéterminé. Analyse de l'efficacité de la croissance vis-à-vis de la formation du nombre de graines. Informations Techniques CETIOM, 94, 3-13.

Pigeaire A., Duthion C., Turc O., 1986. Characterization of the final stage in seed abortion in indeterminate soybean, white lupin and pea. Agronomie, 6, 371-378.

Planchon C., 1984. Résistance à la sécheresse du soja : comportement agronomique et réponses physiologiques, p. 16-22. In R. Blanchet. Rapport "Agronomie, physiologie et voies d'amélioration du soja », 39 p.

Puech J., Lencrerot P., Hernandez M., 1974. Rôle de quelques facteurs du milicu dans la production quantitative et qualitative du soja. I. Croissance, développement et rendement du soja en culture irriguée ou non. Ann. agron., 25, 659-679.

Puech J., Bonnal J. M., Hernandez M., 1977. Observations sur l'importance de l'avortement des organes fructifères de soja placé dans 
différentes conditions écologiques. C.R. Acad. Sci., Paris, 284 D, 2343-2346.

Robelin M., 1963. Contribution à létude du comportement du maïs grain vis-à-vis de la sécheresse. Journces Internationales de l'AGPM 4 avril 1963 , Chantilly.

Saito M., Yamamoto T., Goto K., Hashimoto K., 1970. The influence of cool temperature before and after anthesis on pod-setling and nutrient in soybean plants. Proc. crop. Sci. Soc., Japan, 39, 511 1.519. Shaw R. H., Laing D. R., 1966. Moisture stress and plant response, p. 73-94. In W. H. Picre et al., Plant environment and efficient water use. ASA and SSSA, Madison, Wisconsin.

Sinclair T. R., 1984. Cessation of leal emergence in indeterminate soybcans. Crop Sci. 24, 483-486.
Spaeth S. C., Sinclair T. R., 1984. Soybean seed growth. II. Individual seed mass and component compensation. Agron. J., 76, 128-133.

Specht J. E., Williams J. H., Weibenbenner C. J., 1986. Differential response of soybean genotypes subjected to a seasonal soil water gradicnt. Crop $S_{c i}$. 26, 922-934

Spollen W. G., Wiebold W. J., Scott Glenn D., 1986. Effect of altered intraraceme competition on carbon ${ }^{14}$-labeled assimilate and abscisic acid in soybean. Crop Sci., 26, 1216-1219.

Vidal A., Arnaudo D., Arnoux M., 1981. La résistance à la sécheresse du soja. I. Influence d'un déficit hydrique sur la croissance et la production. Agronomie, 1, 295-302. 